\title{
Opening and Changes of the Firms TIC: Case of Cuts Internet in Political Matter in Democratic Republic of
} Congo

\author{
Julien Bokilo Lossayi \\ Teacher-researcher at the University Marien Ngouabi of Congo \\ Researcher-Associate at the Africa Laboratory in Africa (LAM) Sciences Po Bordeaux
}

Received 17 October 2019;

Accepted 26 October 2019;

Published 4 November 2019

\begin{abstract}
The cuts of Internet in political matter started with "Arab spring" and since then know a fast progression in Africa at the point to become an international public problem today putting in scene the modes in place, in certain African States, and their opponents. Indeed, in what appears as a battle for the control of information and the control of the public opinion, there are on a side the African governments which, to justify the interruption of Internet, propose the need for safeguarding of the law and order like act of sovereignty, in fact the right to prevent the misinformation and any illegal publication of the electoral data. On the other side, there are the oppositions which view this step as the violation of the principles of freedoms, in particular the freedom of expression, at ends of fiddle of the electoral data.

The scientific stake of this analysis, starting from African case studies, and of the RDC in particular, is to reflect on the ambivalence of the decision to cut Internet, in order to as well show the consequences of these restrictions on the economy, the credibility of the elections, the social one and, by the same occasion, to carry a glance on the reaction of the international community.
\end{abstract}

Keywords: Cuts of Internet in Africa, NTIC in Africa, Internet providers, Law and order, public freedoms, regional integration

\section{Introduction}

For a few years, in many African countries, one has attended restrictions by the governments in the access to Internet. These latter often intervene during political demonstrations and social movements launched by opponents, but tend to multiply at the time of the electoral expiries, or with the approach of the examinations of State (this practice is from now on current in many countries in prey with violence's).

In fact, the practice of interruption of Internet was observed for the first time at the time of "Arab springs" in North Africa and Middle East. According to OECD, cuts of Internet in Egypt in 2011, are evaluated to 90 million dollars for five days. Since, one observes a tendency to the universalization of this phenomenon, for example, with the Indian Cashmere where the authorities used of this measure to anticipate violence's.

Thus, the present reflexion study considers the changes induced by information technologies in the companies of subSaharan Africa, in particular from the economic and political points of view.

To this end, the governments of the sub-Saharan States, at rare exceptions, estimate that to cut signal Internet aims at preserving the law and order. They look with much suspicion the social networks which they regard as platforms on which the citizens exchange "gossips and lies". Also, the fact that the social networks are characterized by the absence of filters and control reinforces the mistrust from the authorities of certain Africans who fear the "effect swell of snow" in these spaces generally snuffed by the prompt young people to share information with potentials demonstrators. The bottom, the cuts of signal Internet at the time of the electoral expiries makes it possible the authorities in place to avoid the follow-up in real time of the course of the elections by opponents who, more and more, adopted the practice of the division of the official reports of the electoral operations, office by office, for a compilation of the results. This system enables them to prove with the national and world public opinion their victory, if the mode in place would be tried by the handling of the results. Fearing to have to manage riots and the popular discontent on electoral bottom of holdup, the governments choose the blackout which can go to the total cut of the telephone calls and Internet.

Then, which is the socio-economic and political impact of these interruptions in political matter of Internet? Is this a new manner of making state putsches or it is only of the opportunism of controlling which cuts telecommunications to cheat?

The least which one can say it is that, although these cuts of Internet allow to a certain extent to preserve the law and order, the way in which they are used in Africa shows that this tool formed today part of "repertory of action" political systems, in fact of the capacities in place, at ends of political handling and conservation of being able. However, the repercussion of this practice are not limited solely in the political field, far is necessary some, but extend on the economy and even on the respectability of the country which one calls in question the democratic character and the credibility of the polls which are organized there. 
The literature on the cuts of Internet abounds in the newspapers, rythming the media and political debates, but no serious scientific study on the question was undertaken, except, the analysis of Jean-Loup RICHET which goes back to 2011. His analysis concerns the lessons that Libya of Mouammar Kadhafi learned from the revolution of Egypt of Hosni Moubarak, by carrying out a strategy different from that of Egypt, while remaining closer to that of Iran. But, the increase in the political cuts of Internet in sub-Saharan Africa these last years lead to the multiplication of the reports on the ground. Many people in Africa regard these cuts as political putsches or tool of power allowing policies in place to maintain themselves. They become from now on an international public problem. And, certain scientific theories make it possible to understand and read this behavioral change of certain African political leaders. What the completely interesting study of Richet did not underline, and it remains conceptual. so, the preliminary objective of this analysis is inter alia answering this shelf and proposing a case study on the Democratic Republic of Congo (RDC).

The theory of the agency which comes from the economy is most classically defined by Mr. C Jensen and W H. Meckling (1976).Transposed in political science, this theory makes it possible to treat opportunist behaviors of ruling governments and to analyze information which become asymmetrical between controlling (agent) and the citizens voters (the main thing) during the electoral process. This asymmetry of information causes significant dissensions between these two actors in terms of preferences of public policies (Sanders, 1994). Indeed, the citizens voters delegate to the leaders the organization and the information management on all the electoral process, in exchange of the respect of the rules and democratic principles. However, the uncertainty due to the cuts of the signal Internet which surrounds by many polls, prevents the voters from knowing perfectly the reality of the electoral process. The elected government is the only one to know with precision certain parameters of the process. Benefiting from this informational advantage, it decides to scramble the treatment of the process by the confiscation of the results, and by pursuing other goals that those wished by the citizens, without necessarily losing with the next elections (Galeotti and Breton, 1986). Thus, it should be noted that this opportunist behavior is only possible because there is asymmetry of information for the benefit of the elected government.

The methodology devoted to this study associates the empirical method with the analytical method, in order to jointly mobilize the abstract analytical tools and the factual elements coming from the observation. In an exploratory step in Paris and on the African ground, in particular in Congo-Brazzaville, we collected statistical data near the companies of telecommunication. We then prepared a questionnaire which we managed with the persons in charge for the startup, with a professor of the universities, and we also had discussions with the itinerant salesmen.

Our sales leaflet on the cuts of Internet in political matter is articulated in two parts. Initially, we are interested in the process of the penetration of the multinational firms of mobile telephony, the Internet through its various rates of penetration, and of the relevance of the international law on the question of the right to the expression of the populations(1). Are then analyzed the effects of these "political" interruptions on the economy, the credibility of the political polls, the social plan, and the other forms of transformation consisting with the raising of prices of the Internet in spite of the cuts (2).

The penetration of the firms TIC and its services of access Internet like spaces free expression for the African populations The analysis of the penetration of the firms TIC through its services of access Internet which support the development of the social networks like Twitter, Facebook, Orkut, Badoo and Hi-Five, and of its products like smartphone, makes it possible to understand the degree of penetration of those on the African continent, in filigree, to study its impact at the political level, in particular on the behavior of the established government (elected) with respect to the citizens (voters) who is characterized by the cuts of Internet.

This penetration was done on the African continent to differing degrees, especially thanks to the dynamization of the cooperation South-South which started in 1999, through the rush of the emergent countries like China on the African ground (J Bokilo, 2012).Thus, the presence of these emergent countries and the arrival of new infrastructure as the underwater cable WACS which connects the United Kingdom to Africa supported the evolution of the socio-economic and cultural context on the continent. Thanks to this penetration, the sector of communication and information technologies in Africa offers four principal services: fixed telephony, mobile telephony and Internet. But, within the framework of this reflexion we are only interested in the two last, because although appeared several years afterwards, they knew a faster opening being characterized, for example, by the fact that $75 \%$ of the African hearths were connected via the mobiles in 2018, according to the Deloitte cabinet.

That being, among the 48 sub-Saharan countries, we will analyze the penetration of the firms TIC and its services of access Internet in certain countries of central Africa comparatively with the countries leaders on the continent. It is presented as follows:

Chart No 1: Some indicators on the penetration of the TIC in central Africa, 2016 to 2018.

\begin{tabular}{|l|l|l|l|l|}
\hline Country & Years & \multicolumn{2}{|l|}{ Mobile telephony } & Internet \\
\hline & & $\begin{array}{l}\text { Subscriptions with mobile } \\
\text { telephony for 100 inhabitants }\end{array}$ & $\begin{array}{l}\text { No. of subscribers in } \\
\text { million }\end{array}$ & $\begin{array}{l}\text { Percentage of individuals } \\
\text { using Internet }\end{array}$ \\
\hline CONGO & $\mathbf{2 0 1 8}$ & N/A & 4,9 & N/A \\
\hline & $\mathbf{2 0 1 7}$ & 96,11 & 5056 & 8,65 \\
\hline CAMEROUN & $\mathbf{2 0 1 6}$ & 105,82 & 5424 & 8,12 \\
\hline & $\mathbf{2 0 1 8}$ & N/A & 21,98 & 23,20 \\
\hline & $\mathbf{2 0 1 7}$ & 83,71 & 20135388 & 23,20 \\
\hline GABON & $\mathbf{2 0 1 6}$ & 79,86 & 18717503 & N/A \\
\hline & $\mathbf{2 0 1 8}$ & N/A & 3 & 50,32 \\
\hline CHAD & $\mathbf{2 0 1 7}$ & 131,51 & 2663243 & 48,05 \\
\hline & $\mathbf{2 0 1 6}$ & 149,64 & 2962486 & N/A \\
\hline
\end{tabular}




\begin{tabular}{|l|l|l|l|l|}
\hline & $\mathbf{2 0 1 6}$ & 38,65 & 5585709 & 5,00 \\
\hline Center AFRICA & $\mathbf{2 0 1 8}$ & N/A & N/A & N/A \\
\hline & $\mathbf{2 0 1 7}$ & 25,23 & 1175389 & 4,34 \\
\hline & $\mathbf{2 0 1 6}$ & 27,17 & 1248346 & 4,00 \\
\hline EQUATORIAL GUNINEE & $\mathbf{2 0 1 8}$ & & & \\
\hline & $\mathbf{2 0 1 7}$ & 92,00 & 11700 & 11,40 \\
\hline & $\mathbf{2 0 1 6}$ & 89,63 & 11110 & 9,80 \\
\hline
\end{tabular}

Sources: According to the data of the world data base on the indicators of telecommunication/updated in November 2018/available at the following address: < https://www.itu.int/en/ITU-D/Statistics >/digital Report/ratio 2018 of We Are Social/JDN according to the World Bank, available to the following address: <www.journaldunet.com >/Ecofin Agency, February 12, 2019/(Given consulted 27/03/2019).

While comparing starting from this table $\mathrm{n}^{\circ} 1$, the key indicator related to the percentage of the people using Internet of the DRC with the three countries leaders of the mobile telephony of Central Africa, in particular Cameroun, Congo-Brazzaville and Gabon, we note that the DRC remains very far behind with $8,62 \%$ of individuals using Internet against 50,32\% for Gabon, for the year 2017 , and 6, $21 \%$ for the DRC against 48, $05 \%$, for Gabon for the year 2016. Whereas in terms of the number of subscribers, the
DRC is largely at the head with 35375246 of subscribers against 2 663243 of subscribers for Gabon in 2017, and 28889317 of subscribers for the DRC against 2962486 of subscribers for Gabon for the year 2016.

At side of the penetration of the mobile firms of these countries of central Africa, one can also quote those in countries African leaders of the telephony, of which the DRC forms part.

Chart No 2: Some statistics of 2011 on principal countries leaders of telecommunications in Africa

\begin{tabular}{|l|c|c|c|c|c|c|c|}
\hline Country & Population & \multicolumn{2}{|c|}{ Mobile telephony } & \multicolumn{4}{|c|}{ Internet High Flow } \\
\hline subscribers & $\begin{array}{c}\text { Rate of } \\
\text { penetration }\end{array}$ & $\begin{array}{c}\text { No. of Net } \\
\text { surfers }\end{array}$ & $\begin{array}{c}\text { Leaves the Net } \\
\text { surfers in the } \\
\text { Population }\end{array}$ & $\begin{array}{c}\text { No. of } \\
\text { subscribers } \\
\text { High flow }\end{array}$ & $\begin{array}{c}\text { Rate of } \\
\text { penetration }\end{array}$ \\
\hline Nigeria & $155,215,573$ & 95167308 & $58,58 \%$ & 46190431 & $28,43 \%$ & 215675 & $0,13 \%$ \\
\hline Ethiopia & $90,873,739$ & 14126659 & $16,67 \%$ & 932077 & $1,10 \%$ & 27043 & $0,03 \%$ \\
\hline Egypt & $82,079,636$ & 83425145 & $101,08 \%$ & 29399597 & $35,62 \%$ & 1820446 & $2,21 \%$ \\
\hline DRC & $71,712,867$ & 15677123 & $23,13 \%$ & 813091 & $1,2 \%$ & 813091 & \\
\hline South Africa & $49,004,031$ & 64000000 & $126,83 \%$ & 10596595 & $20,95 \%$ & 907000 & $0,02 \%$ \\
\hline Tanzania & $42,746,620$ & 25666455 & $55,53 \%$ & 5546218 & $12,00 \%$ & 3500 & $1,80 \%$ \\
\hline Kenya & $41,070,934$ & 26980771 & $64,84 \%$ & 11650723 & $28,00 \%$ & 48961 & $0,01 \%$ \\
\hline Algeria & $34,994,937$ & 35615926 & $98,99 \%$ & 5037227 & $14,00 \%$ & 1000000 & $2,78 \%$ \\
\hline
\end{tabular}

Sources: According to the JDN, the World Bank, available at the following address: <www.journaldunet.com < http://www.journaldunet.com >>(Given consulted on March 1, 2019).

From these tables $\left(n^{\circ} 1\right.$ and $\left.n^{\circ} 2\right)$, one can note that in spite of the progression of the rates of penetration of the mobile and the number of subscribers in all the countries of the two groups, the first of the classification of the countries of the group of the African leaders, in particular Nigeria, are largely at the head with 95167308 subscribers in 2011, which represents $58 \%$ of the rate of penetration and 46190431 users of Internet, against the first of the countries of central Africa which is Cameroun which has 10 486614 subscribers, with $52,35 \%$ of the rate of penetration and 1 001518 Net surfers for the same year 2011.

In addition, no country of central Africa appears among the African leaders. Central Africa remains the area with the rate of weakest penetration of the Internet in the world (12\%), far behind (49\%), West Africa North Africa (39\%), East Africa (27\%), and Southern Africa (51\%). But, in a general way, the appearance of new economic actors on the African market contributed to the development of the DIGITAL. In fact, in 2018 one can count:
435 million users of Internet, with a rate of penetration of $34 \%$;

191 million active users on the social networks, with a rate of penetration of $15 \%$;

172 million active users of the social networks mobile, with a rate of penetration of $14 \%$.

From the reading of various tables $\left(\mathrm{n}^{\circ} 1\right.$ and $\left.\mathrm{n}^{\circ} 2\right)$, one can recognize that the evolution of the penetration of these multinational firms of mobile telephony and Internet is partly due to the progression of the indicators of access. It is on the one hand about the increase in the number of subscribers on the cellular telephone for 100 inhabitants, and on the other hand of the competence of the African populations, because it is clear that the rates of elimination of illiteracy adult and schooling to the secondary are in rise in the majority of these countries. What explains the fact that the annual growth rate of penetration of mobile telephony in these countries varies between $30 \%$ and $50 \%$ (J Hausman, 2015).

Chart no 3: Some indicators of mobile telephony moving in the African leaders countries

\begin{tabular}{|c|c|c|c|c|c|c|c|c|}
\hline \multirow[t]{2}{*}{ Country } & \multirow{2}{*}{$\begin{array}{l}\text { Leader by } \\
\text { no. of } \\
\text { subscribers }\end{array}$} & \multirow{2}{*}{$\begin{array}{l}\text { Firms in the } \\
\text { countries } \\
\text { leaders }\end{array}$} & \multirow[t]{2}{*}{ Country of origin } & \multirow{2}{*}{$\begin{array}{l}\text { No. of } \\
\text { subscribers } \\
\text { in million in } \\
2018\end{array}$} & \multicolumn{3}{|c|}{$\begin{array}{l}\text { No. Total of subscribers Per } \\
\text { country in million }\end{array}$} & \multirow{2}{*}{$\begin{array}{l}\text { Rate of } \\
\text { penetration/Po } \\
\text { sition between } \\
\text { bracket }\end{array}$} \\
\hline & & & & & 2018 & 2017 & 2016 & \\
\hline
\end{tabular}




\begin{tabular}{|c|c|c|c|c|c|c|c|c|}
\hline Nigeria & 1 & MTN & South Africa & 58,197 & 154 & $\begin{array}{l}144920 \\
170\end{array}$ & $\begin{array}{l}154342 \\
168\end{array}$ & $83 \%(2016)(6)$ \\
\hline & & Airtel & India & 36,608 & & & & \\
\hline & & Vmobile & Nigeria & 5,2 & & & & \\
\hline \multirow[t]{3}{*}{ Egypt } & 2 & Vodafone & $\begin{array}{l}\text { Great Britain and Egypt } \\
(44,7 \%)\end{array}$ & 39,647 & 97,8 & $\begin{array}{l}102958 \\
194\end{array}$ & $\begin{array}{ll}97 & 791 \\
441 & \end{array}$ & $\begin{array}{lll}109 & \% & (2018) \\
(5) & & \end{array}$ \\
\hline & & Orange & France & 29,475 & & & & \\
\hline & & Etisalat & Plain Arabemirates & 27,5 & & & & \\
\hline \multirow[t]{3}{*}{$\begin{array}{l}\text { South } \\
\text { Africa }\end{array}$} & 3 & Vodacom & Great Britain & 43,838 & 96 & $\begin{array}{ll}88 & 497 \\
610 & \end{array}$ & $\begin{array}{ll}82 & 412 \\
880 & \end{array}$ & $\begin{array}{lll}153 & \% & (2018) \\
(\mathbf{1}) & & \end{array}$ \\
\hline & & MTN & South Africa & 31,191 & & & & \\
\hline & & Cell C & South Africa & 20 & & & & \\
\hline Ethiopia & 4 & $\begin{array}{l}\text { Ethio } \\
\text { Telecom }\end{array}$ & Ethiopia & 49,1 & 49,1 & $\begin{array}{ll}39 & 600 \\
000 & \end{array}$ & $\begin{array}{ll}51 & 224 \\
000 & \end{array}$ & $48 \%(2018)(8)$ \\
\hline \multirow[t]{3}{*}{ Algeria } & 5 & Djezzy & Algeria & 15,5 & $\begin{array}{l}45,1 \\
(2016)\end{array}$ & $\begin{array}{ll}45 & 845 \\
665 & \end{array}$ & $\begin{array}{ll}47 & 041 \\
321 & \end{array}$ & $\begin{array}{lll}112 & \% & (2018) \\
(4) & & \\
\end{array}$ \\
\hline & & Mobilis & Algeria & 16,5 & & & & \\
\hline & & $\begin{array}{l}\text { OoredooAlger } \\
\text { ia }\end{array}$ & Qatar & 13,696 & & & & \\
\hline \multirow[t]{3}{*}{ Morocco } & 6 & $\begin{array}{l}\text { Morocco } \\
\text { Telecom }\end{array}$ & $\begin{array}{l}\text { Plain Morocco and } \\
\text { Arab Emirats }(53,09)\end{array}$ & 18,380 & 42 & $\begin{array}{ll}43 & 916 \\
066 & \end{array}$ & $\begin{array}{ll}41 & 513 \\
933 & \end{array}$ & $\begin{array}{lll}123 & \% & (2018) \\
(2) & & \end{array}$ \\
\hline & & Orange & Group French & 14,300 & & & & \\
\hline & & Inwi & Morocco-Koweït & 9,372 & & & & \\
\hline \multirow[t]{2}{*}{ Kenya } & 7 & Safaricom & South-African group & 29,780 & 38,5 & $\begin{array}{l}42815 \\
109\end{array}$ & $\begin{array}{l}38982 \\
188\end{array}$ & $82 \%(2016)(7)$ \\
\hline & & Celtel & $\begin{array}{l}\text { Netherlands, rested by } \\
\text { Mo Ibrahim of gold } \\
\text { Sudanese woman }\end{array}$ & 1,6 & & & & \\
\hline \multirow[t]{3}{*}{ Ghana } & 8 & MTN & South Africa & 17,790 & 31,8 & $\begin{array}{ll}36 & 751 \\
761 & \\
\end{array}$ & $\begin{array}{ll}38 & 305 \\
078 & \\
\end{array}$ & $\begin{array}{lll}121 & \% & (2018) \\
(3) & & \\
\end{array}$ \\
\hline & & Vodafone & The United Kingdom & 9,800 & & & & \\
\hline & & Tigo & Luxembourg & 4,847 & & & & \\
\hline \multirow[t]{3}{*}{ RDC } & 9 & Vodacom & The United Kingdom & 12,830 & 28,8 & $\begin{array}{ll}35 & 375 \\
246 & \\
\end{array}$ & $\begin{array}{ll}28 & 889 \\
317 & \\
\end{array}$ & $\begin{array}{l}30,6 \%(2018) \\
(9)\end{array}$ \\
\hline & & Orange & France & 10,602 & & & & \\
\hline & & Airtel & India & 8 & & & & \\
\hline
\end{tabular}

Sources: According to the data of Financial reporting, "Annual results 2018 - MTN Central Group/Agency intelligence, available at the following address: < www.Cia.gov/Statistiques of the international Union télécommunications/statista, fr.statista.com > (Given consulted 23/03/2019).

This chart no 3 on the countries leaders of mobile telephony, clearly shows that a country can be a leader in terms of the number of subscribers and to be in the sixth position with regard to the rate of penetration, the case of Nigeria which finds itself in the 6th place whereas first at the beginning.

Chart No 4: Some information on the telephone companies mobile having divides of it the market of Africa

\begin{tabular}{|l|l|l|l|l|l|}
\hline \multicolumn{2}{|l}{ Country } & $\begin{array}{l}\text { The first 3 Firms } \\
\text { leaders }\end{array}$ & Country of origin & $\begin{array}{l}\text { No. of subscribers in } \\
\text { million }\end{array}$ & $\begin{array}{l}\text { Sales turnover of } \\
\text { billion FCFA }\end{array}$ \\
\hline Congo & $\mathbf{1}$ & Airtel & India & 2548 & +50 \\
\hline & & MTN & South Africa & 2546 & 50 \\
\hline Cameroun & $\mathbf{2}$ & MTN & South Africa & 7,1 & 135,5 \\
\hline & & Orange & France & 7,245 & 184 \\
\hline Gabon & $\mathbf{3}$ & Airtel & India & 0,649388 & 4,90 \\
\hline & & $\begin{array}{l}\text { Gabon Telecom } \\
\text { Mobile }\end{array}$ & $\begin{array}{l}\text { Subsidiary company of } \\
\text { Morocco Telecom }\end{array}$ & 1222444 & 10,36 \\
\hline Chad & $\mathbf{4}$ & Tigo (Millicom) & Luxembourg & 3,2 & N/A \\
\hline Central Africa & $\mathbf{5}$ & Airtel & India & N/A & N/A \\
\hline & & Orange & France & 5 & N/A \\
\hline $\begin{array}{l}\text { Equatorial } \\
\text { Guinea }\end{array}$ & $\mathbf{6}$ & Telecel & Mexico & 5 & N/A \\
\hline
\end{tabular}


Sources: According to the data of the digital Report/ratio 2018 of We Are Social/of Arpce Congo (given consulted 01/03/2019)/Observatory of the markets of the Internet of Gabon (given consulted it 20/02/2019).

From charts no3 and no4, one can notice that firms of the emergent countries become increasingly present and leaders on the market of central Africa.

In addition, this new context also supported the appearance of new practices, new needs and new possibilities of action and exchanges. In fact, one of the immediate implications of this change results in the surge of the products "made in China" ( $J$ Bokilo, 2012). At this time, one can notice that what is usually regarded as luxury products reserved for the African easy classes and African Middle Classes, in particular the televisions, mobile phones and other electronic accessories whose price is radically dropping with for example, the passage of the average price of a telephone $2 \mathrm{G}$ of $150 \$ 2003$ to $75 \$$ in 2008 . Between 1998 and 2009, the rate of African equipment passed from 0,53 devices for 100 inhabitants to 42,82 devices for 100 inhabitants.
Besides, in 2018, more than 350 million African have of Smartphones, and this market has come to know more and more a great progression. And, this is what explains the study of the Deloitte cabinet presented in April 2018 which estimates that:"660 million African people should thus be equipped with a smartphone from here to 2020, against 336 million in 2016... That will represent a rate of penetration of about $55 \%$, and nearly one halfmilliard of access Internet will be done then via smartphones... 67 $\%$ of the mobile phones users in Africa likely declared to be buying a smartphone in the 12 next months...." However, the computers still remain an inaccessible product for certain social classes. All the social layers don't have the necessary means to get them. The tendency which shows that the TIC is having much importance in the African continent is clearly shown in the chart below:

Chart No 5: Key indicators related to the TIC for the IUT/BDT Africa

\begin{tabular}{|c|c|c|c|c|c|c|c|c|c|c|c|c|c|c|c|c|c|}
\hline & & \multicolumn{8}{|c|}{ In million } & \multicolumn{8}{|c|}{ For 100 inhabitants } \\
\hline & & $\begin{array}{l}201 \\
1\end{array}$ & $\begin{array}{l}20 \\
12\end{array}$ & $\begin{array}{l}201 \\
3\end{array}$ & $\begin{array}{l}20 \\
14\end{array}$ & $\begin{array}{l}201 \\
5\end{array}$ & $\begin{array}{l}201 \\
6\end{array}$ & $\begin{array}{l}201 \\
7\end{array}$ & $\begin{array}{l}201 \\
8\end{array}$ & $\begin{array}{l}20 \\
11\end{array}$ & $\begin{array}{l}201 \\
2\end{array}$ & $\begin{array}{l}201 \\
3\end{array}$ & $\begin{array}{l}201 \\
4\end{array}$ & $\begin{array}{l}201 \\
5\end{array}$ & $\begin{array}{c}201 \\
6\end{array}$ & 2017 & $\begin{array}{c}201 \\
8\end{array}$ \\
\hline 1 & $\begin{array}{l}\text { Subscriptions } \\
\text { withfixedtele } \\
\text { phony }\end{array}$ & 12 & 11 & 10 & 10 & 10 & 11 & 9 & 10 & 1,4 & 1,3 & 1,1 & 1,1 & 1,1 & 1,1 & 0,9 & 0,9 \\
\hline 2 & $\begin{array}{l}\text { Subscriptions } \\
\text { with mobile } \\
\text { telephony } \\
\text { (mobile } \\
\text { phone) }\end{array}$ & 441 & $\begin{array}{l}51 \\
0\end{array}$ & 581 & $\begin{array}{l}64 \\
4\end{array}$ & 714 & 714 & 744 & 781 & $\begin{array}{l}51, \\
9\end{array}$ & 58,4 & 64,7 & 69,7 & 75,3 & 73,2 & 74,4 & 76,0 \\
\hline 3 & $\begin{array}{l}\text { Active } \\
\text { subscriptions } \\
\text { with high } \\
\text { mobile flow }\end{array}$ & 23 & 51 & 94 & $\begin{array}{l}12 \\
1\end{array}$ & 181 & 212 & 248 & 305 & 2,7 & 5,9 & 10,5 & 13,1 & 19,0 & 21,8 & 24,8 & 29,7 \\
\hline 4 & $\begin{array}{l}\text { Subscriptions } \\
\text { with high } \\
\text { fixed flow }\end{array}$ & 2 & 2 & 3 & 4 & 4 & 5 & 6 & 6 & 0,2 & 0,2 & 0,3 & 0,4 & 0,4 & 0,5 & 0,6 & 0,6 \\
\hline \multicolumn{10}{|c|}{ In million } & \multicolumn{8}{|l|}{$\%$} \\
\hline 5 & $\begin{array}{l}\text { Householdswi } \\
\text { th a } \\
\text { Computer }\end{array}$ & N/A & $\begin{array}{l}\mathrm{N} / \\
\mathrm{A}\end{array}$ & $\begin{array}{l}\mathrm{N} / \\
\mathrm{A}\end{array}$ & $\begin{array}{l}\mathrm{N} / \\
\mathrm{A}\end{array}$ & N/A & N/A & N/A & $\begin{array}{l}\mathrm{N} / \\
\mathrm{A}\end{array}$ & 5,8 & 6,3 & 6,6 & 7,5 & 8,2 & 7,6 & 8,8 & 9,2 \\
\hline 6 & $\begin{array}{l}\text { Households } \\
\text { with access } \\
\text { Internet to } \\
\text { residence }\end{array}$ & N/A & $\begin{array}{l}\mathrm{N} / \\
\mathrm{A}\end{array}$ & $\begin{array}{l}\mathrm{N} / \\
\mathrm{A}\end{array}$ & $\begin{array}{l}\mathrm{N} / \\
\mathrm{A}\end{array}$ & N/A & N/A & N/A & $\begin{array}{l}\mathrm{N} / \\
\mathrm{A}\end{array}$ & 5,6 & 7,3 & 8,7 & 11,2 & 14,1 & 16,7 & 18,8 & 22,0 \\
\hline 7 & $\begin{array}{l}\text { People using } \\
\text { Internet }\end{array}$ & 68 & 85 & 107 & $\begin{array}{l}13 \\
2\end{array}$ & 164 & 190 & 213 & $\begin{array}{l}\mathrm{N} / \\
\mathrm{A}\end{array}$ & 8,0 & 9,9 & 12,1 & 14,5 & 18,0 & 19,8 & 22,1 & 24,4 \\
\hline
\end{tabular}

Sources: According to the World Base Data on the indicators of telecommunication/updated 2018/available in November at the following address: < https://www.itu.int/en/ITU-D/Statistics > (given consulted 27/03/2019).

While observing this chart $n^{\circ} 5$ on the key indicators related to the TIC in Africa, we can determine the level of penetration of the TIC which have direct impact on the freedom of expression of the populations and consequently on the policy. The analysis of these indicators can be done in two moments as shown in the above two large columns. On the first in million, concerning the subscriptions with fixed telephony, we note that the tendency is the fall when we start from 2011 with 12 million subscribers to 2018 with 10 million subscribers. Whereas the subscriptions of the mobile telephony which more supports the development of the social networks is in full expansion, because they doubled while passing from 441 million in 2011 to 781 million in 2018.By taking the same indicators for the column which consists in analyzing the indicators for 100 inhabitants, one notes that fixe is still falling, because the number of subscribers by 100 inhabitants passed from $1,4 \%$ in 2011 to $0,9 \%$ in 2018 .Thus, when we wonder why this depression tendency in the sector of fixed telephony?

The technical reason is one of the causes of the fall of subscription in this sector. When the sector of mobile telephony requires only the installation of the antennas, that of fixed telephony requires more technical works.

In addition, when we consider the indicators of the households for 100 inhabitants with computer or access Internet to residence and the indicator on the people using Internet for 100 
inhabitants, we note that clear increases, for example on the last case on the people, the subscriptions passed from $8,0 \%$ in 2011 to $24,4 \%$ in 2018

On the whole, the teaching that we can draw from all the above charts, it is that the sector of the TIC is in full expansion on the African continent, which constitutes a real problem or a direct threat for the authoritarian regimes (elected) which wish to manage the elections and other political activities at closed door. Because the Internet is difficult and even complicated to control for the critics. For that reason, Boas (2000) speaks about "dilemma of the dictator".

Thus, conscious of the importance of the TIC in the development of the democratic culture, especially in countries where the media are controlled by the ruling governments, and with the aim of protecting the African users from the TIC, the organisations of the Nations and the African Union published a certain number of principles on the freedom of expression and access to the Internet. To this end, the United Nations Human Rights Council (UNHRC), adopted in July 2016, a resolution on the promotion and the enjoyment of human rights on internet. It condemns unambiguous measures which aim at:"preventing intentionally or disturbing the access to the dissemination of information online, violation of the international law of the human rights".

In the same context, the African Commission on Human Peoples' Rights (ACHPR) affirmed in November 2016 the statement of principles on the freedom of expression in Africa according to which:"each one has the possibility of exerting the right to the freedom of expression and the access to information without discrimination".

Transformations of the uses of the TIC

Since 2015, the majority of the African governments have been referring to administrative interruptions of the Web, in particular the cut of Internet network on the mobile phones and the SMS. These cuts of the social networks like Whatsapp, Facebook intervene for the electoral process, the period of the political demonstrations and during the examinations of State as in Ethiopia. The RIPE.net site which supervises the state of the network in the world shows well the brutal fall of the number of IP addresses (what shows that the routers are in stop) declared in certain African countries for the election time and of the demonstrations. It is starting from these cuts which the Agency France Presses (AFP) estimates for these two last years that the access to Internet network was cut during 236 days cumulated in Africa. In addition to that, the confiscation of the materials of the channels of televisions, radios and cancellations of the accreditations of the foreign special envoys, the case of that of Radio France Internationale (RFI) in DRC; moreover, the sending home of the representatives of the international institutions, such as the sending home within 48 hours of Bart Ouvry, the ambassador of the UE in DRC, by the government of the DRC during the electoral process . Thus, one observes some authoritarian lockings of the political system by the cuts of Internet and the change of the methods of management of the social protests by the authorities. Whereas the access to Internet in Africa is considered by many people as a tool which promotes the democracy, the freedom of expression, unlike traditional means of communication, in particular broadcasting and the remote transmission which are often under the control of the established powers in Africa. Furthermore, even if the cut of the Internet allows the leaders to sow doubt so as to create a conflictual situation to maintain themselves in power. In fact, the Internet is among others regarded as an oxymora on the continent (J-L Richet, 2011).

Additionally, it appears from the report revealed in Johannesburg by the Coalition for the International Politics on Technologies of the Communication and the Internet in Southern and East Africa (CIPESA), located in Kampala in Uganda, that 12 countries resorted to these measures. The targeted countries by this report are: the Democratic Republic of Congo, the Republic of Congo, Cameroun, Ethiopia, Gambia, Togo, Chad, Niger, Burundi, the Central African Republic, Mali, Gabon, Botswana, Ghana, Kenya, Malawi, Tanzania, Uganda, Zambia and Zimbabwe. Thus, the map of these cuts is viewed as follows:

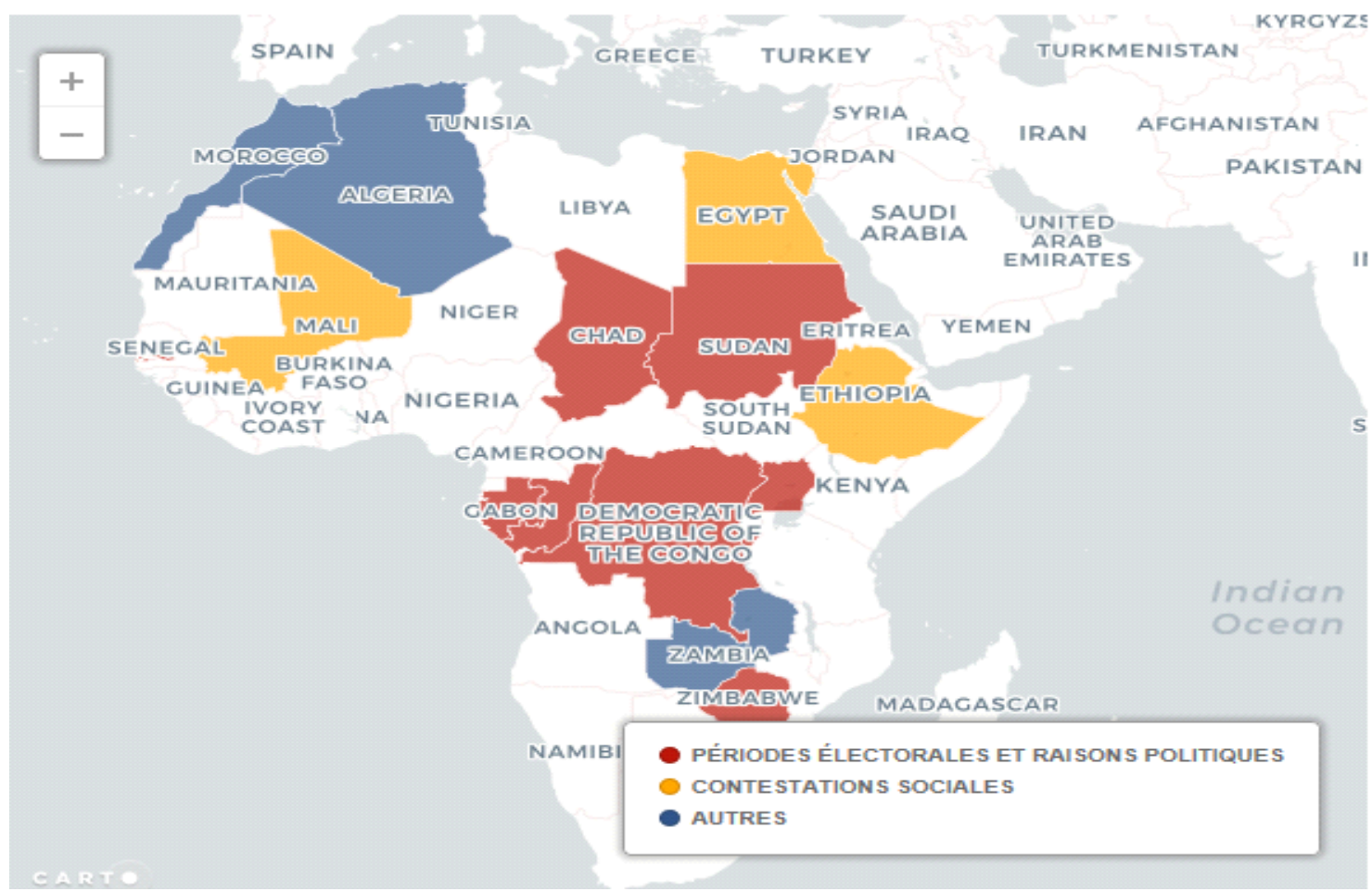

Source: Access Now and Dyn (consulted 15/03/2019). 


\section{Chart No 1: The various African countries which cut the Internet at the time of the elections and the demonstrations}

The illustration of this chart shows that the electoral and political reasons dominate. But, obviously, the goal of these cuts of Internet would aim at disorganizing the calls to the gatherings and avoiding the broadcast of information in real time by the opponents.

\section{Economic and political consequence of the interruptions of} Internet in political matter

The cuts of Internet in certain sub-Saharan African countries during the electoral process endangered the savings in these countries. In fact, Internet becomes a tool or vector of power, because it helps create richness, therefore the growth through their number of subscribers, in particular from the users of the units, data and SMS, and it is part of the Africans' daily newspaper.

Indeed, these restrictions in the access to the Internet constitute a very handicap for these countries. Consequently, the majority of their economic activities, be they formal or informal, currently depends on the Internet.

Thus, when one takes the case of the banking environment, one notices that the Banks, the Agencies of exchange and transfer as Western Union are as victims as the firms of mobile telephony (mobile money) of these cuts of Internet which also cause, as a result, harm to the national economy. In fact, the E-Banking services and the slot-machines (ATM) of certain banks, used by a great number of the customers of these companies, remain closed during the cut of Internet. To that are added Terminals of Mobile Payment (TPM) generally used in the trades, supermarkets, restaurants, coffees, bars, hotels which remain penalized.

Along with that, it can be added in the batch, the platforms of the markets online (sites of sales), the sites of information or the media online and the startups whose activities depend on Internet as the cyber cafes also come to a standstill, therefore are all constrained with a layoff and a breach of contract of confidence, between these structures and their customers. It is from this point of view that Josias Ndinga of the cyber cafe "God bless you" in Brazzaville thinks, on the economic impact of the cuts of Internet on the economies of the African countries, that: "the cut of Internet signal is operated by the suppliers of access Internet at the request of the leaders, under pretexts of the maintenance of order and security throughout the national territory. It is obvious that this measure has disastrous economic effects, because the economic management strongly depends on the technologies of information and communication. The communication of the companies and the administrations cannot do without the data-processing tool. Cutting the Internet singal creates an embargo on the information flow in these entities and creates a strong disturbance in their operating way, by preventing them from communicating with the customers or the partners.

The negative impact also concerns the suppliers of access Internet themselves which, in addition to the deplorable image that such a measure gives them, undergo, undoubtedly, a forced fall of their productivity. But, obviously, which quantified evaluations can one make of this measure? Regarding a political injunction, the operators of Internet for various reasons among which that of the protection of their license, do not take the risk to publish the quantified evaluations of this forced fall of consumption ".

In the process, one can also note some residual effects of these interruptions of Internet on the activities of the economic operators. This situation can follow-up to several scenarios like the fact that certain entrepreneurs certainly saw their deals being delayed, not concluded or compelled to the payment of enormous penalties simply because of this practice however independent of their will.

In addition, one can also quote the consequences of these cuts on the activities of the Embassies as such that of France which set up a system of SMS in the process of request for visas, the case of that of the DRC. That is also valid for the reservation of the plane tickets.

Having regard to the above, it is estimated that one day of deprivation of Internet, in these African economies from now on connected and inter-connected in situ and ex situ, is a hard blow for the saving and the public finance in these countries (because of the lack of payment of taxes, taxes and other rights owed in these States).In 2017 the CIPESA revealed that since 2015 the administrative cuts of Internet costed these African countries the equivalent of 200 million euros. But, the figures have more than tripled and exceeded more than 3 billion dollars, since the election of Felix TSHISEKEDI to the presidency against Martin Fayulu in DRC. Globalement, this situation is presented as follows:

Chart no 6: Economic impact of cyber-censorship in certain African countries of 2015-2019.

\begin{tabular}{|l|c|l|l|l|}
\hline \multicolumn{2}{|l|}{ Country } & $\begin{array}{l}\text { A number of days of cuts of } \\
\text { the Internet }\end{array}$ & $\begin{array}{l}\text { Cost of the cuts of the } \\
\text { Internet of billion dollars }\end{array}$ & $\begin{array}{l}\text { Activities causing the cuts of the } \\
\text { Internet }\end{array}$ \\
\hline DRC & $\mathbf{1}$ & $\begin{array}{l}28 \text { days (either of December } \\
31,2018 \text { to the 27/01/2019) }\end{array}$ & +3 & During the electoralprocess \\
\hline Ethiopia & $\mathbf{2}$ & 36 days & $0,132,1$ & $\begin{array}{l}\text { Demonstrations the day before the } \\
\text { examinations }\end{array}$ \\
\hline Congo-Brazzaville & $\mathbf{3}$ & 49 days & 0,72 & At the time of the referendum \\
\hline Cameroun & $\mathbf{4}$ & 93 days & 0,38 & $\begin{array}{l}\text { Demonstration in the anglophone } \\
\text { Provinces which claim independence }\end{array}$ \\
\hline Togo & $\mathbf{5}$ & 5 days & 0,243507 & $\begin{array}{l}\text { Manifestations of the opposition } \\
\text { against the established power }\end{array}$ \\
\hline
\end{tabular}




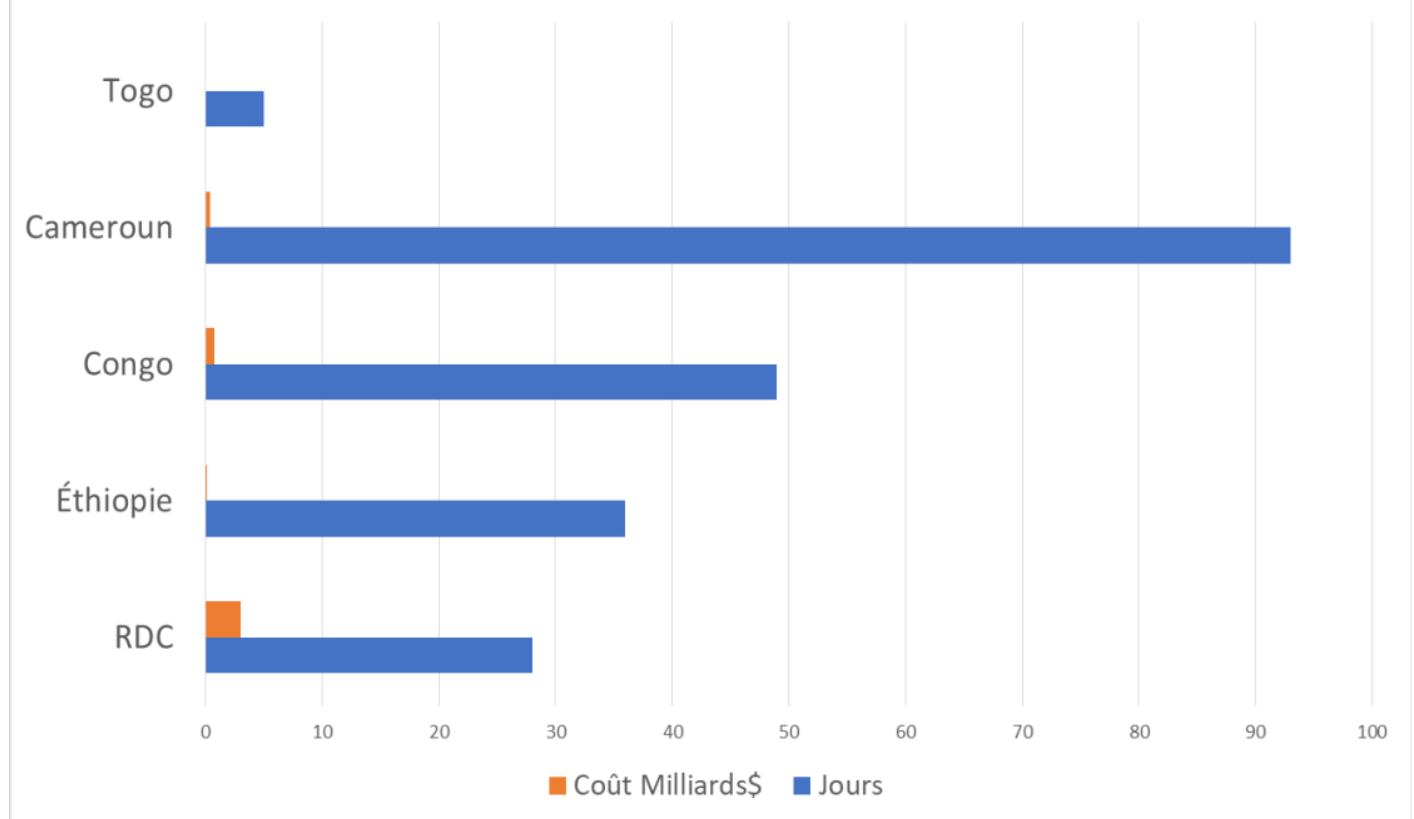

Sources: According to the data of the CIPESA, Young Africa of September 29, 2017 and Radio Okapi (MONUSCO) of 27/01/2019, Available at the following address:< https://www.radiookapi.net >/Joan Tilouine, "To cut Internet, the new temptation of the African modes", LeMondeAfrique, Available at the following address: $<w w w . l e m o n d e . f r>$, published on 02 January 2019/available at the following address: < http://www.dw.com/Academi of DW > (data consulted 15/03/2019).

The illustration of the indicators related to the impact of cybercensorship in certain African countries of this chart $n^{\circ} 6$ and the graph inform us starting from the first column that the number of days of cuts of the Internet in DRC is the lowest with 28 days against 93 days for Cameroun, but the cost of those in DRC is 3 billion dollars higher than Togo with the weakest cost, that is to say 243507 dollars. This cost is higher in RDC compared to these other countries, because of the high number of subscribers of mobile telephony of this country which is at 28,8 million against for example 21,98 million for Cameroun for the year 2018. The high cost of the losses in DRC confirms the fact that the sector of telecommunications represents the second larger contributor of the State, in terms of finances, after the mining sector, according to Israel Mutala in Radio operator Okapi .

The importance of this order can be shown by taking the case of the sales turnovers of August 2018 from the data of certain firms of telephony which present themselves as follows:

Chart no 7: Receipts of the principal firms of the DRC mobile telephony in 2018

\begin{tabular}{|l|l|c|}
\hline & Companies & Receipts of billion dollars \\
\hline $\mathbf{1}$ & Airtel & 1,900 - dated \\
\hline $\mathbf{2}$ & Vodacom & 1,130 - dated \\
\hline $\mathbf{3}$ & Orange & 1,250 - dated \\
\hline $\mathbf{4}$ & Africell & 0,640 - dated \\
\hline
\end{tabular}

Source: The intervention of Israel Mutala in Radio operator Okapi (MONUSCO) on 27/01/2019, Available at the following address: < https://www.radiookapi.net > (Consulted 10/03/2019).

Daily losses are evaluated to million American dollars as well in the telecom sectors, banking as services and itinerant salesmen (Sagna, 2009). To this end, I put questions to various salesmen in Brazzaville on the impact of the cuts of Internet on their everyday life. To this interrogation, a "rescuer" who wanted to remain anonymous answered me: "At each time that there is cut, I often have evil to feed my family. Frankly, I do not see what these cuts bring to us, whereas there are often soldiers during the elections, and there is almost no disorder ".In the same direction, the politologist Darrel West, think American tank Brookings Institution, estimated that the economic consequences of 81 cuts of Internet in 19 country between June 2015 and July 2016, in terms of losses rise to 2,4 billion dollars (approximately 2,1 billion euros)

Politically, these cuts have consequences on the electoral processes in certain African countries, because, with difficulty, the countries were inserted in closed door due to the interruptions of Internet. Also, these cuts feed suspicions which undermine most of the time the credibility of the electoral processes on the continent. Whatever the given reasons, many observers have evil to give credit to an election organized in the blackout which legitimates the dispute of the opponents fustigating the electoral holdup. In this connection, Andre Patient Bokiba, after an interview that he granted to me in the context of my survey in Africa, estimates on the question of the obstacle to the transparency of the results of the poll that : "it would initially have to be recalled that all our African constitutions guarantee the sovereignty of the people, the freedom of expression and the information flow. The cut of Internet signal is a serious obstacle to the information flow. In electoral context, this measure favours the cheating and the fraud on the results of the vote, therefore the diversion of the expression of the will of the citizens, to the extent that this operation leads to a massive diversion of the results of the elections in favour or in discredit of such or such candidate, because, should it be pointed out, the cut of telecommunications is not guided by an obsession of transparency; what may seem like a putsch, especially in the optics of the retention of power. Any interference in the treatment of the electoral process by the confiscation of the true results is an act of force ".

In the case of the DRC, 40 million of Congolese people were called to vote on Sunday December 31, 2018, to as elect the successor of Joseph Kabila as the national and provincial deputies. For these elections, Kinshasa declined any logistic help from the United Nations and any mission of Western observation (of the external audit). Curiously, the afternoon of the day of the elections, 
the sending of SMS was impossible "for one unspecified duration, on decision of the government". It was followed from there, at the following day, the suspension of the access to Internet and the telephone social networks. The international community, particularly, most of Western countries highly reacted against this governmental action.

France deplored, during the closed-door meeting of the Security Council on the question of the poll of December 2018 in DRC, that: "the access control to these services of communication could blame the credibility of the elections".

In addition, on their side, the European Union representatives (UE), of the United States of Canada, of Switzerland, of France, of Belgium, of the United Kingdom, of the Netherlands and Sweden in Kinshasa, in a joint official statement of January 1, declared:"We ask the government not to block the means of communication and in particular the access to Internet as well as the media".

Nevertheless, the United States sanctioned in an official statement broadcasted on February 22, 2019 by the secretariat of American State, by prohibiting the delivery of visas to five personalities of three institutions of the DRC, among which appear Corneille Nangaa (President of the CENI) its assistant and one of his advisers, Aubin Minaku (national Parliament), and Benoit Lwamba (President of the constitutional Court)

However, on the one hand, the action of cut "policies" of the Internet by the congolese government caused delays to the CENI in the processes of counting, centralization and compilation of the results for the 179 local centers of the DRC. And, on the other hand, this interruption also made complex the work of the electoral observers, as such the episcopal Conference. It delayed for one day the very awaited presentation of their preliminary report on the voting operations. The coalition of the opposition ' $\mathrm{CACH}$ ' directed by Felix Tshisekedi, proclaimed President, denounced these processes and speaks even about significant fraud. The coalition "LAMUKA" around the candidate of the other opposition Martin Fayulu estimates that the Internet cut "augurs fraud and cheating being done in this precise moment", according to his director of countryside Pierre LUMBI joined by the AFP. Finally, the camp of Kabila gained very largely all the other elections, and this situation created a climate of dissension between the established government, the opposition and the citizens (Sanders 1994, Galeotti and Breton, 1986).

\section{Another form of transformation of the penetration against the populations in Africa}

A long with cutting Internet, certain African governments go so far as to adopt dissuasive measures by increasing Internet taxes with an aim of dissuading the users to have access to the various services of the Internet. It is the case of the ougandan government where president Yoweri MUSEVENI undertook himself to announce the entry into force of this new tax.

Indeed, since July 1, 2018, the ougandan Net surfers who wish to connect themselves to the social networks are subjected to the payment of a daily tax of 200 shilling, that is to say approximately 30 FCFA per day, 930 FCFA per month and 11000 FCFA per annum. And, to assure itself of an effective collection, the government charged the mobile companies of telephony with taking this tax directly. If one takes a longer view, the amount of the tax seems ridiculous, but the Web Foundation then estimates that it represents all the same $10 \%$ of the cost of connection for the low incomes, the purchase of $1 \mathrm{~Gb}$ of dated represents $40 \%$ of the average wages for most modest in Uganda. This new tax concerns more than 50 social networks, among which Facebook, Twitter, Instagram and Whatsapp.

On the whole, the characteristic causes of opportunism of the established government (elected) which appear by the cuts of Internet are the fear of losing the capacity and the refusal of political alternation. In fact, this phenomenon actually takes its source from a badly acquired power, political routines and the difficulties in respecting the democratic rules by the leaders or elected officials who lead to the disputes or manifestations of the voters, from which we assist at a new form of putsches. As a matter of fact, this study finally confirms the application of the grid of reading of the theory of the agency, which was largely used as framework of reference to the study of the opportunist behaviors of the African leaders (elected) towards their citizens (voters).

\section{Conclusion}

This analysis leads to confirm the assumption according to which the cuts of Internet allow to a certain extent to preserve the law and order, but they have disastrous consequences on the savings of these countries and on the credibility of the polls, because the pretext is ambivalent.

At all events, these interruptions go against the freedoms of expression and neither favour stability nor confidence between certain elected officials and the voters support. This crisis of confidence endangers as well democracy, the economic activity as social and national cohesion. In background, the question of African integration arises about the scene of world affairs, especially when the african rulers illegally elected are found in large-masses with the Western leaders elected without any dispute.

Regarding the urgency of this international public problem, many tracks and objects of research remain to be invested in the analysis of the electoral processes and the cover of the political and social demonstrations against the bad governance of certain African countries.

The other interest for this question remains to shad lights on the negative impact that these cuts can in particular have, in particular, in the process of investment in the sector of new technologies which occupy today a significant place in the integration of the African companies. Lastly, it remains to determine the border between the safeguarding of the law and order and fundamental freedoms.

\section{Data Availability}

I have indicated all the sources I have used and some data can be accessed via the internet and others need to do the groundwork.

\section{Conflicts of Interest}

Julien Bokilo, I declare on my honor that there is no conflict of interest in the publication of my article.

\section{Funding Statement}

I finance my research alone.

\section{Bibliographical references}

[1] Adrianaivo Mr., Kpodar, K., "Mobile Phons, financial inclusion and grouth", Review of Economics and Institutions, vol. 3, N 2, 2012. 
[2] Africapresse.Paris., "Tendencies of the sector of the techs, media and télécoms in Africa", published on 18 April, available to the following address <: https://www.africapresse.paris

http://www.africapresse.paris >>, 2018.

[3] Ahmed, D., The "Tic:a chance for Africa?", in Gabas Jean-Jacques, numerical Company and development in Africa:uses and public policies, Paris, Karthala, 2004.

[4] Amossé T, Guillemot D., Moatty, Rosanvallon, J., "Abstract Exchanges and working relationships per hour of the organisational changes and computerization", Noisy-the-Large, the EEC, research report, 2010, $161 \mathrm{p}$.

[5] Ansoft, I., Strategy of the development of the company, Editions Men and Techniques, Paris, 1968.

[6] Bazzara, A., "Cuts of social networks and Internet:Africa explodes all the records ", the Economic Point, published the 21/10, 2016.

[7] Belton, L, De Coninck, F., "Of the borders and the bonds.Topologies of deprived and the professional for the mobile workers ", Networks, N 140, pp. 67-100, 2007.

[8] Ben Néfissa, S., "Authoritative Locking and general change of the relationship between the State and the company in Egypt", Mediterranean Junctions, 4, N 75, 2010, pp. 137-150.

[9] Boas, Taylor C., "The Dictator' S Dilemma:The Internet and U.S. Policy Toward Cuba ", The Washington Quarterly, 23.3, 2000, pp. 57-67.

[10] Bokilo Lossayi Julien, "Firmes TIC et responsabilité sociétale des entreprises en Afrique, cas du Congo », Revue Africaine et Malgache de recherche scientifique de sciences juridiques et politiques, $\mathrm{n}^{\circ} 2$, juillet 2019, pp. 59-74.

[11] Bokilo Lossayi, J., Introduction to the African social policies, Paris, Persée, 2019.

[12] Bokilo Lossayi, J., China in Congo-Brazzaville: Strategy of the rooting and effects on the development in Africa, Paris, Harmattan, 2012.

[13] Bokilo Lossayi Julien, China in Africa: Competition between China, traditional trade partners of Africa and BRIC countries, Paris, L'Harmattan, 2011.

[14] Cardoso Paved C, Rosa Mr., "Reflexions on the social integration of the NTIC and the educommunication", Distances and Savoirs, vol. 9, 2, 2011, pp. 207-217.

[15] Chambat P., 1994 "Uses of the TIC:evolution of the problems ", information Technologies and company, vol.6, n3, pp.249-270.

[16] Cheminat, J., "Cut of Internet estimated at 65 million euros for Egypt", available to the following address: $<<$ http://www.lemondeinformatique.fr/actualites/lire-a-cutD-Internet-estimee-A-65-million-D-euro-for-legypte32812.html, consulted page 14/04/11 >>,2011.

[17] Gutter-Loquay, A., "Mobile telephony in cities African.An adaptation successful to the local context ", geographical space, 1, Volume 41, 2012, pp. 82-93.

[18] Darbon, D. and Provini, O., "To think the public action in African contexts:stakes of a decentralization ", Government and public action, April-June, vol. 07, N 2, 2018, pp.9-29.

[19] Djénéba T., 2007 "Integration of the TIC in education in Mali, inventory of fixtures, stakes and evaluation", Distances and Savoirs, vol. 5, 1, 2007, pp. 67-82.
[20] Egré, P., "Internet, new territory of fight for the political opponents in exile", Men and Migrations, n1240, 2002, pp. 53-61.

[21] Fernandez Julian, Relations internationales, Paris, Dalloz, 2019.

[22] Gabas, J-j., Numerical Company and development in Africa:uses and public policies, Paris, Karthala, 2004.

[23] Galeotti, G. and Breton, A. (1986), 'Left Year economic theory of political', Kyklos, 39: 47-75.

[24] Gerstle, J., (1996), 'Information and sensitivity of the voters to the economic situation', French Review of Political Science 46, (5): 46-45.

[25] GSMA., "Mobile Money in the Democratic Republic of Congo:Market research on the customer requirements and opportunities in the field of the payments and services financial ", InterMedia, July, 2013.

[26] Holeindre, J-v. ,The Trick and the force.Another history of the strategy, Perrin, 2017.

[27] Hootsuite., "DIGITAL in Africa 2018", we social are, 2018.

[28] Hausman, J, Liu, Z., "Mobile Phons in developing countries.Working paper, Consortium one financial systems and poverty ", Available At:< http//economics.yale.edu/sites/defaut/files/

[29] hausman07-Oct.-2014.pdf.Accessed 24 Mar >,2015.

[30] Jensen, Mr. C, Meckling, W H, "Theory of the Firm:Managerial Behavior, Agency Cost and Capital Structure ", Newspaper of Financial Economics, 3, 305360, 1976.

[31] Kalathil, S., Boas, T.C., "Open Networks, Closed Modes:The Impact of the Internet one Authoritarian Rule ", ED.Carnegie Endowment for International Peace, Washington cd., 2003.

[32] Kluver, R., Qiu, K.L., "Clouded, the Internet and Democracy", Rhetoric and Reality:The Internet Challenge for Democracy in Asia, ED.Indrajit Banerjee, Singapore:Eastern University Press, 2003.

[33] Farmhouse I, Radcliffe D., "Viral Mobile payments go:Mr.-weighed in Kenya ", March, SSRN.Available At: $<$ http//papers.ssrn.com $>2010$.

[34] Mathieu L., "Report/ratio with the policy, cognitive dimensions and pragmatic prospects in the analysis for the social movements", French Review of political science, 52, 1, 2002, pp.75-100.

[35] Richet J-L, "Internet and uses: what Libya learned from the revolution in Egypt ", Chaire Raoul-Dandurand in strategic and diplomatic studies - UQAM/disponible with the following address < https://dandurand.uqam-Ca >, 2011.

[36] Rosanvallon, P., Economic Liberalism. History of the idea of market, Paris, Not Threshold, 1989.

[37] Sagna O., "Private Télécentres of Senegal, end of successes story", in Cheneau-Loquay (A.)(coord.), Access to new technologies in Africa and Asia.TIC and universal service, Paris, Harmattan, 2009.

[38] Sanders George D., "Tiebout Migrants and the median voters have users of accounting information", Research in Governmental and Nonprofit Accouting, vol. 8, pp. 137-155, Jai Press, 1994.

[39] Smith A., Sorbets C., Leadership Political and the territory, executives of analysis in debate, Rennes, PURE, 2003. 
[40] Tcheng, H., Huet, J-Mr., Viennese, I, Romdhane, M., "Télécoms, factor of development in Africa", the expansion Review Management, 2, N 129, 2008, pp. 110-120.

[41] Thierry Côme, Gilles Rouet (2015), Innovations managériales, enjeux et perspectives, coll . Local \& Global, L'Harmattan, Paris 2015, 245 p.

[42] Tilouine, J., "To cut Internet, the new temptation of the African modes", Le Monde Afrique, available to the following address: $<$ www.lemonde.fr, published on January $02>, 2019$.
[43] Touraine, A., "Theory and practical of a sociology of the action", Sociology and companies, vol. 10, N 2, 1978, pp. 149-188.

[44] Yam-Pukri., "Dynamic and roles economic and social of the abstract sector of the TIC in Center and West Africa.Case of Burkina Faso, Cameroun and Senegal ", Final Research report, Burkina Faso, Yam-Pukri Association, Research centers for the international development, June 2010,139 p.

[45] Zuckerman, E., "Intermediary Censorship", Access Controlled:the Shaping of Power, Rights and Rules in Cyberspace,

ED.MIT

Press,

2010 